\title{
The corixid Sigara (Subsigara) distincta (Fieber, 1848) in the Pyrenees: a first record for Spain and an unsolved taxonomic puzzle
}

\author{
Víctor Osorio ${ }^{1, *}$ (iD), María Ángeles Puig ${ }^{1}$ (D), Teresa Buchaca ${ }^{1}$ (D) Hyunbin $\mathrm{Jo}^{2}$ (iD) and Marc \\ Ventura $^{1}(\mathrm{D})$ \\ ${ }^{1}$ Centre for Advanced Studies of Blanes, Spanish Research Council (CEAB-CSIC), Integrative Freshwater \\ Ecology Group (IFE), Accés a la Cala St. Francesc, 14, Blanes 17300, Girona, Catalonia, Spain. \\ 2 Fisheries Science Institute, Chonnam National University, Yeosu, 59626, Republic of Korea. \\ * Corresponding author: victor.osorio.alv@gmail.com
}

Received: $13 / 04 / 20$

Accepted: 17/08/20

\begin{abstract}
The corixid Sigara (Subsigara) distincta (Fieber, 1848) in the Pyrenees: a first record for Spain and an unsolved taxonomic puzzle

The occurrence of Sigara (Subsigara) distincta (Fieber, 1848) in Spain is reported for the first time based on specimens collected in the Pyrenean municipality of Vielha e Mijaran (Central Pyrenees). Multiple captures between 2014-2018 indicate that $S$. distincta successfully established itself in Lake Vilac (1640 m a.s.l.), a small mesotrophic water body under Atlantic climate. High-throughput sequencing (HTS) technologies are valuable tools for freshwater bioassessment and detection of rare taxa. A DNA metabarcoding study carried out on macroinvertebrate samples supported the presence of S. distincta in the lake, thus corroborating morphological identification of imagines and greatly facilitating the identification of immature stages, which otherwise would be a difficult if not impossible task. By means of DNA barcode sequencing of individuals from Lake Vilac, we detected a rare haplotype of $S$. distincta previously recorded in Northern Germany. Our sequences showed to be clearly segregated from other publicly available $S$. distincta sequences, according to phylogenetic analysis. The results support the hypotheses of the existence of two highly divergent $S$. distincta lineages across Europe. A major taxonomic revision of Subsigara Stichel, 1935 species, combining both molecular and morphological approaches will be needed to shed light on the causes of high genetic intraspecific variation in $S$. distincta and related species.
\end{abstract}

Key words: Corixidae, Hemiptera, DNA barcode, DNA metabarcoding, high mountain lake

\section{RESUMEN}

El coríxido Sigara (Subsigara) distincta (Fieber, 1848) en los Pirineos: una primera cita para España y un rompecabezas taxonómico no resuelto

Se reporta por primera vez para España la especie Sigara (Subsigara) distincta (Fieber, 1848), en base a individuos recolectados en el municipio pirenaico de Vielha e Mijaran (Pirineos centrales). La captura de individuos durante 2014-2018 indica que S. distincta se ha establecido con éxito en la laguna de Vilac (1640 m s.n.m.), una pequeña masa de agua mesotrófica bajo la influencia de clima atlántico. Las tecnologías de secuenciación de alto rendimiento (HTS) demostraron ser herramientas valiosas para la monitorización de ecosistemas acuáticos continentales y la detección de taxones raros. Un estudio de metabarcoding llevado a cabo sobre las muestras de macroinvertebrados de la laguna apoyó la presencia de S. distincta, corroborando la identificación morfológica de los imagos y facilitando en gran medida la identificación de estadios inmaduros, que de otra forma hubiera sido muy difícil, si no imposible, identificar. Mediante la secuenciación del código de barras genético de individuos de la laguna de Vilac, detectamos un raro haplotipo previamente registrado en el norte de Alemania. Nuestras secuencias mostraron estar claramente segregadas respecto otras secuencias de S. distincta disponibles públicamente, según los análisis filogenéticos. Los resultados apoyan la hipótesis de la existencia de dos linajes altamente divergentes de S. distincta en Europa. Una revisión taxonómica de las especies de Subsigara Stichel, 1935, combinando aproximaciones moleculares y morfológicas, será necesaria para aportar más información sobre las causas de la alta variabilidad genética intraespecifica de $\mathrm{S}$. distincta $y$ las especies cercanas. 
Palabras clave: Corixidae, Hemiptera, código de barras genético, DNA metabarcoding, lago de alta montaña

\section{INTRODUCTION}

The genus Sigara Fabricius, 1775 is the largest of the family Corixidae in terms of the number of species, and has a cosmopolitan distribution (Jansson, 1986; Polhemus et al., 1995). Sigara species show very diverse morphological traits and inhabit both freshwater and saline water bodies (Jansson, 1986; Carbonell et al., 2011). The 27 European species are currently allocated into eight subgenera, and a total of three species in the subgenus Subsigara Stichel, 1935 are recorded from Spain: Sigara (Subsigara) falleni (Fieber, 1848), Sigara (Subsigara) fossarum (Leach, 1817), and Sigara (Subsigara) scotti (Douglas \& Scott, 1868) (Aukema, 2013). All of them are infrequently encountered in Spain, and their records are limited to few localities (Nieser et al., 1994).

Sigara (Subsigara) distincta (Fieber, 1848) is widely distributed throughout the Palearctic region, from the British Isles throughout Northern and Central Europe to Asia as far as the River Lena (East Siberia), but has been rarely found in South-western Europe and never recorded in Spain (Jansson, 1986; Polhemus et al., 1995; Elder \& Schaeffer, 2014). It is known to develop in ponds and small streams, but also in both oligotrophic and eutrophic lakes (Jastrey, 1981; Nieser, 1982). The freshwater habitats it occupies are commonly characterised by low electrical conductivity and clear waters moderately poor in nutrients. It has a special preference for the boundary between open water and dense vegetation patches (Nieser, 1982; Lock et al., 2013). The species has been described to primarily be a detritus feeder, and thus having an omnivore diet (Popham et al., 1984).

S. falleni is also distributed throughout most of Europe through to Siberia and China, and a close relationship with $S$. distincta in terms of morphology was reported by Jansson (1986). A recent study, aiming at taking the first steps towards setting up a comprehensive library of DNA barcodes for Central Europe aquatic Heteroptera (Havemann et al., 2018), confirmed that the two species are very close from an evolutionary point of view. The extent to which hybridization may occur between $S$. distincta and S. falleni in regions where they coexist remains unknown. Moreover, the availability of genetic resources for the species of the subgenus Subsigara on public sequence databases is currently very limited, thus hindering the assessment of phylogenetic relationships across distant geographic regions. However, the application of massive parallel sequencing (i.e. high-throughput sequencing, HTS) to DNA barcoding is allowing to feasibly address questions not only relating to the ecology and evolution of organisms, but also conservation of biodiversity (Kress et al., 2015).

This paper deals with the discovery of the species in a locality in the Spanish Pyrenees, which is the first record of S. distincta for Spain. In addition, we contribute with the DNA barcode sequencing of specimens from the reported population. In doing so, we provide new insights into the genetic variability of the species and the European distribution of its molecular lineages.

\section{METHODS}

\section{Study site}

Specimens were collected in Lake Vilac, which is in the municipality of Vielha e Mijaran $\left(42^{\circ} 42^{\prime}\right.$ $\left.33.3^{\prime \prime} \mathrm{N}, 0^{\circ} 48^{\prime} 50.1^{\prime \prime} \mathrm{E}\right)$. The lake is in the Aran Valley (Central Pyrenees), at $1640 \mathrm{~m}$ a.s.l., on the northern side of the Pyrenees with the influence of an Atlantic climate. It has a W-SW orientation, and its catchment is located on a carbonated aquifer, consisting of a small endorheic basin of glacial origin (ACA, 2004). The total lake area is around $0.4 \mathrm{ha}$, and its maximum depth is $2.7 \mathrm{~m}$. The lake bottom substrate is almost exclusively composed of sands and fine silt enriched with organic matter.

The lake is included in the list of European Union's Special Areas of Conservation (SAC code ES5130006) (European Commission, 1992). It is home to a habitat of community inter- 
est (oligotrophic-mesotrophic waters of lakes and lagoons with Littorelletea uniflorae or Isoëto- $\mathrm{Na}$ nojuncetea vegetation - HCI 3130) and the only known population of the water-plantain Luronium natans (L.) Raf. in the Spanish Pyrenees. Some protected amphibian species of Community Interest (Habitats Directive; European Commission, 1992) such as Alytes obstetricans (Laurenti, 1768) and Rana temporaria Linnaeus, 1758 also inhabit the site.

\section{Sampling and morphological identification}

Lake Vilac was sampled multiple times from 2014 to 2019 within the framework of the LIFE+ LIMNOPIRINEUS project (www.lifelimnopirineus.eu). In addition, conservation and monitoring actions for HCI 3130 and the species of Community Interest were carried out there as part of this project. In every sampling event, several parameters relating to the physical and chemical environment of the lake were measured. Water samples for laboratory analyses of conductivity, $\mathrm{pH}$, alkalinity, nutrient concentration and chlorophyll- $a$ (Chl- $a$ ) were taken from the water column at the deepest point of the lake with a UWITEC water sampler. The measured nutrient parameters were total nitrogen (TN), dissolved inorganic nitrogen (DIN) and total phosphorus (TP). The analytical methods followed the procedures described by Ventura et al. (2000). The littoral macroinvertebrate communities were also studied during the visits to the lake over a five-year period. For this study we used the samples from five sampling dates: 16/7/2014, 7/8/2014, 10/10/2014, 4/8/2016 and 30/7/2018.

We sampled the macroinvertebrate community in the littoral zone using a sweep sampling technique and a standard D-frame net $(250 \mu \mathrm{m}$ mesh size). Habitat type dominances were previously estimated by in situ exploration of the littoral zone of the lake along the entire perimeter. These relative dominances were eventually used for weighing the sampling effort among all present habitats ( $30 \times 1 \mathrm{~m}$-long sweeps). Samples were conserved in the field with absolute ethanol to a final concentration of ca. $70 \%$ for later observation and sorting under the binocular stereomicroscope (Olympus SZ60, Japan). The final taxonomic resolution achieved for most of the groups was genus level. Corixids were put aside and identified to the species level where possible using appropriate literature (Murillo, 1985; Jansson, 1986; Nieser et al., 1994).

\section{Molecular methods}

Bulk macroinvertebrate samples collected on 16/7/2014, 7/8/2014 and 10/10/2014 were sequenced as part of a broad DNA metabarcoding study on high mountain aquatic fauna. A short fragment (Leray fragment, $313 \mathrm{bp}$ ) of mitochondrial Cytochrome c Oxidase I gene (COI) was targeted for that purpose (Leray et al., 2013) (molecular laboratory and bioinformatics methods are included in the Supplementary information, available at http://www.limnetica.net/en/ limnetica). Targeting a short marker region is a common strategy in metabarcoding approaches so as to increase amplification success and deal with degraded DNA (Thomsen \& Willerslev, 2015).

In addition, we sequenced a 658 bp fragment of COI (the Folmer region; Folmer et al., 1994) from two Sigara individuals: one female identified as S. distincta (captured on 7/8/2014), and one V-instar nymph assigned to the species triplet S. (Subsigara) distincta, S. (Subsigara) falleni, and Sigara (Subsigara) fallenoidea (Hungerford, 1926) (captured on 10/10/2014). The DNA was extracted with the QIAGEN DNeasy Blood and Tissue Kit (QiagenTM, 170 Hilden, Germany), proceeding in accordance with the manufacturer's protocol. Bidirectional amplification was performed using the primers jgLCOI490 (5 TTITCIACIAAYCAYAARGAYATTGG - 3) and jgHCO2198 (5 -TAIACYTCIGGRTGICCRAARAAYCA - 3) (Geller et al., 2013) following the standards of the DNA barcode of life (Ivanova et al., 2009). The total reaction volume $(25 \mu \mathrm{L})$ consisted of $1 \times \mathrm{PCR}$ buffer (Silverstar, Eurogentec), $1.5 \mathrm{mM} \mathrm{MgCl} 2,0.2 \mathrm{mM}$ of each dNTP, $0.2 \mu \mathrm{M}$ of each primer, $2 \mu \mathrm{L}$ of template DNA, 1 U Taq polymerase, and UV light-sterilized mQ-H2O. PCR amplifications involved a denaturing step of $1 \mathrm{~min}$ at $95{ }^{\circ} \mathrm{C}$, five cycles of $40 \mathrm{~s}$ at $94{ }^{\circ} \mathrm{C}, 40 \mathrm{~s}$ at $45^{\circ} \mathrm{C}$ and $60 \mathrm{~s}$ at $72{ }^{\circ} \mathrm{C}$, followed by 35 cycles of $40 \mathrm{~s}$ at $94{ }^{\circ} \mathrm{C}, 40 \mathrm{~s}$ at $51{ }^{\circ} \mathrm{C}$ and $60 \mathrm{~s}$ at $72{ }^{\circ} \mathrm{C}$ and a final elongation of 
$5^{\prime}$ at $72{ }^{\circ} \mathrm{C}$ (Prosser et al., 2013). PCR products of them were purified using NucleoFast 96 PCR plate (Macherey-Nagel) and sequenced on an ABI 3730 capillary sequencer (Secugen, Madrid, Spain). The resulting sequences were aligned together with sequences of other relevant Sigara species retrieved from the BOLD database (Ratnasingham \& Hebert, 2007) using the MAFFT algorithm (Katoh et al., 2002) in Geneious Prime version 2020.0.5 (Kearse et al., 2012).

The phylogenetic relationships of the individuals barcoded in this work were assessed in the European Subsigara species context. Publicly available sequences for the following species were found in the BOLD database: $S$. distincta, $S$. falleni, S. scotti, S. fossarum, S. fallenoidea and Sigara iactans Jansson, 1983. All sequences, including the entire Folmer (658 bp) region were downloaded (retrieved in February 2020), and considered in the following steps. Some European species, however, were not covered in the database: Sigara (Subsigara) daghestanica Jansson, 1983, Sigara (Subsigara) italica Jaczewski, 1933, and Sigara (Subsigara) longipalis (J. Sahlberg, 1878). The species Sigara (Sigara) striata (Linnaeus, 1758) was used as the outgroup.

To select the best model of nucleotide substitution, the jModelTest algorithm (Posada, 2008) was applied on the alignment of sequences. Then the species' phylogeny was computed using the
Bayesian inference (BI) implemented in MrBayes version 3.2.6 (Huelsenbeck \& Ronquist, 2001), the Maximum Likelihood (ML) approach in RAxML 8.2.11 (Stamatakis, 2014), and the Maximum Parsimony (MP) in PAUP* 4.0a166 (Swofford, 2003). In BI, two parallel runs of four Monte Carlo Markov chains were run for 3 million generations, trees were sampled every 100 generations, and the first $25 \%$ of sampled trees were discarded as a burn-in phase. In PAUP*, heuristic searches were conducted with tree bisection-reconnection branch swapping and ten random sequence taxon additions; branch support was evaluated by nonparametric bootstrapping with 1000 pseudoreplicates (both in MP and ML).

\section{RESULTS}

\section{Habitat characterisation}

During the study period, Lake Vilac had an alkaline water, with mean alkalinity of $845.3 \mu \mathrm{eq} / \mathrm{L}$ and conductivity $117.4 \mu \mathrm{S} / \mathrm{cm}$, and the $\mathrm{pH}$ was slightly basic (mean 8.8) (Table 1). Its mean ice-free temperature was $15.1^{\circ} \mathrm{C} \pm 0.4$ (max. $\left.26.1^{\circ} \mathrm{C}\right)$. The ice-free period lasted around eight months per year (232.3 days), freezing approximately in mid-November and melting at the end of March. Mean DIN concentration was $11.0 \mu \mathrm{g} / \mathrm{L}$. Total phosphorus (TP) concentrations and Chl- $a$

Table 1. Environmental characterisation of Lake Vilac for the study period. The mean, standard deviation, and minimum and maximum measured values are provided for each parameter. Water temperature corresponds to the mean for the whole ice-free period. Caracterización ambiental de la laguna de Vilac para el período de estudio. Se incluye la media, la desviación estándar y los valores mínimos y máximos registrados para cada parámetro. La medida de temperatura del agua corresponde a la media de todo el periodo libre de hielo.

\begin{tabular}{cccccccccc}
\hline & $\begin{array}{c}\text { Maximum } \\
\text { depth } \\
(\mathrm{m})\end{array}$ & $\begin{array}{c}\text { Water } \\
\text { temperature } \\
\left({ }^{\circ} \mathrm{C}\right)\end{array}$ & $\begin{array}{c}\text { Conductivity } \\
(\mu \mathrm{S} / \mathrm{cm})\end{array}$ & $\begin{array}{c}\text { Alcalinity } \\
(\mu \mathrm{eq} / \mathrm{L})\end{array}$ & $\mathrm{pH}$ & $\begin{array}{c}\mathrm{TN} \\
(\mu \mathrm{g} / \mathrm{L})\end{array}$ & $\begin{array}{c}\mathrm{DIN} \\
(\mu \mathrm{g} / \mathrm{L})\end{array}$ & $\begin{array}{c}\mathrm{TP} \\
(\mu \mathrm{g} / \mathrm{L})\end{array}$ & $\begin{array}{c}\text { Chl- } a \\
(\mu \mathrm{g} / \mathrm{L})\end{array}$ \\
\hline Mean & 2.2 & 15.1 & 117.4 & 845.3 & 8.8 & 519.0 & 11.0 & 24.5 & 3.7 \\
$\mathrm{SD}$ & 0.3 & 0.4 & 13.9 & 195.7 & 0.7 & 135.6 & 5.6 & 12.5 & 3.9 \\
Min. & 1.7 & 13.6 & 97.7 & 613.2 & 7.41 & 273.3 & 3.3 & 9.2 & 0.2 \\
Max. & 2.7 & 26.1 & 145.6 & 1237 & 9.82 & 711.6 & 22.1 & 52.2 & 14.8 \\
\hline
\end{tabular}




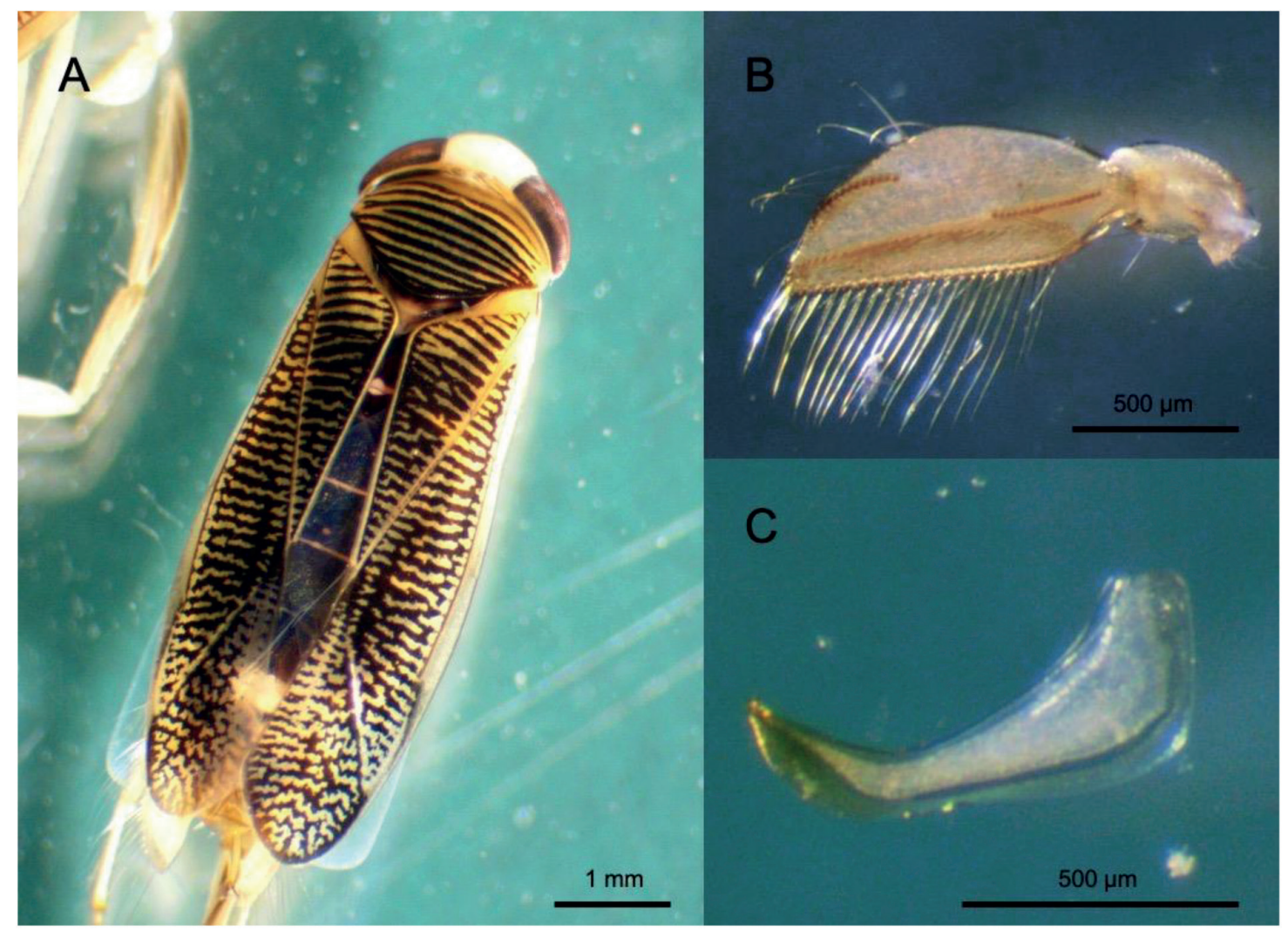

Figure 1. Characteristic features of male specimens of $S$. distincta: A - hemelytral pattern, B - pala, C - right paramere. Rasgos característicos de los individuos macho de S. distincta: $A$ - patrón hemelitral, $B$-pala, $C$ - parámero derecho.

indicated that the lake was mesotrophic (mean TP of $24.5 \mu \mathrm{g} / \mathrm{L}$ and Chl- $a 3.7 \mu \mathrm{g} / \mathrm{L}$; Table 1).

\section{Corixidae specimens}

Four corixid species were morphologically identified in the samples considered from Lake Vilac: S. (Subsigara) distincta, Sigara (Pseudovermicorixa) nigrolineata (Fieber, 1848), Arctocorisa carinata carinata (C.R. Sahlberg, 1819) and Corixa punctata (Illiger, 1807). S. distincta captures in macroinvertebrate samples were distributed as follows: 7/08/2014, 4 exx. (4우);

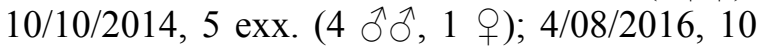
exx. (10우우).

Fully developed male individuals of $S$. distincta were easily recognized from the other species in the subgenus by the shape of their right paramere and in particular by their characteristic pala (Jansson, 1986) (Fig. 1). The morphology of the females collected matched the description of $S$. distincta provided by Höregott \& Jordan (1954), but we were aware that some distinctive features, such as the obtuse angles of lateral corners of pronotum, are not always reliable for identification (Jansson, 1986).

Nymph of $A$. carinata and $S$. nigrolineata were easily distinguished in samples, in contrast to those belonging to the subgenus Subsigara whose identification yielded ambiguous results as nymph keys led us to the species triplet $S$. distincta/S. falleni/S. fallenoidea. Their nymphal instars are not possible to distinguish in most cases (Jansson, 1969; Savage, 1999). Juveniles assigned to that species triplet were found in samples taken on 16/7/2014 (37 exx.), 7/8/2014 (30 exx.), 10/10/2014 (8 exx.), 4/8/2016 (1 ex.) and 30/7/2018 (5 exx.). 


\section{Genetic analyses}

\section{DNA metabarcoding}

The metabarcoding approach confirmed the presence of $S$. distincta DNA in all sequenced bulk macroinvertebrate samples. A single Molecular Operational Taxonomic Unit (MOTU) was taxonomically assigned to the species. Although S. distincta showed a low read abundance, ranging between $0.01-0.06 \%$ of total reads per sample, it was the most abundant corixid species (S. nigrolineata ranging between 0.0004-0.01\%, and $A$. carinata between $0-0.03 \%$ of total reads per sample). Detection of DNA from corixid species was in agreement with the findings made in samples under the stereomicroscope.

\section{DNA barcoding}

The two COI barcode sequences obtained from F1 (NCBI accession number: MT310973) and N1 (MT310972) individuals were separated by only one mutational step, and they were assigned to $S$. distincta according to the BOLD Identification Engine (against Species Barcode Records identification database). The sequence of F1 was identical to a haplotype of $S$. distincta found by Havemann et al. (2018) in Northern Germany (BOLD sequence ID: BCEAB435-16). There was a difference in only one nucleotide in N1 when compared to the abovementioned German haplotype. The MOTU assigned to $S$. distincta in the metabarcoding approach was identical to F1 and $\mathrm{N} 1$ for the shorter COI fragment targeted.

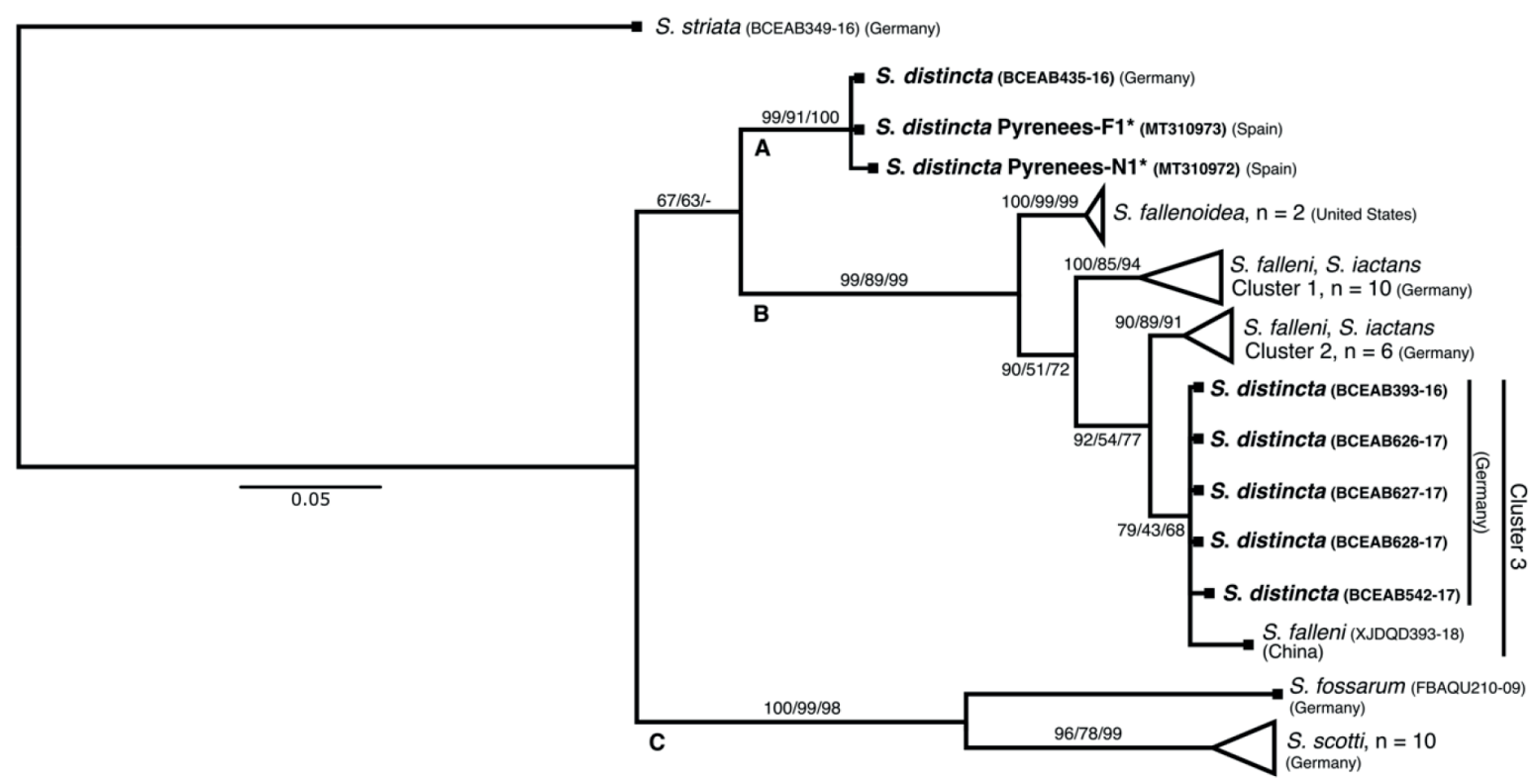

Figure 2. Relationships among the Pyrenean sequences of $S$. distincta obtained in this work (marked with an asterisk) and other species of the subgenus Subsigara retrieved from the BOLD database (sequence IDs are given in the figure or in the text). Sequences assigned to $S$. distincta are marked in bold. The tree was constructed using a Bayesian model-based phylogenetic inference on the Folmer region of mitochondrial COI gene. Branch support is provided by Bayesian inference, Maximum Likelihood and Maximum Parsimony analyses. An empty field in branch support (-) implies differing topology for the branch in the Maximum Parsimony analysis (The letters A, B, and C letters are used in the text for clarification). Relaciones entre las secuencias pirenaicas de $\mathrm{S}$. distincta obtenidas en este trabajo (marcadas con un asterisco) y otras especies del subgénero Subsigara extraídas de la base de datos BOLD (los identificativos de las secuencias se incluye en la figura o en el texto). Las secuencias asignadas a S. distincta están resaltadas en negrita. El árbol fue construido mediante inferencia filogenética basada en el modelo Bayesiano sobre la región de Folmer del gen mitocondrial COI. Se proporciona el soporte de la rama para la inferencia Bayesiana, el análisis de Máxima Verosimilitud y Máxima Parsimonia. El campo vacío en el soporte de la rama (-) implica una topología diferente para la rama en el análisis de Máxima Parsimonia (las letras A, B y C son usadas en el texto para su aclaración). 


\section{Phylogenetic analysis}

Phylogenetic relationships between the sequences obtained in this work and other species of the subgenus Subsigara are shown in figure 2. F1 and N1 were clustered together with the sequence BCEAB435-16 in a well-supported branch. The topology of all three computed phylogenetic trees was coincident, with the exception of the insertion of branch $\mathrm{A}$, which was a sister branch of $\mathrm{B}$ and $\mathrm{C}$ in the Maximum Parsimony tree. We observed a clear divergence of F1 and N1 from the $S$. distincta sequences in cluster 3 (4.9-5.2\% dissimilarity, Kimura 2-parameter distance), which were closely related to $S$. falleni and $S$. iactans. On the whole, $S$. distincta sequences showed to be split into two well-differentiated lineages. Dissimilarity values between F1 and N1 sequences and $S$. fallenoidea (BOLD sequences ID: UAMIC2157-14, UAMIC2170-14) were of 5.1-5.4 \%. S. falleni and S. iactans sequences did not follow any clear pattern of segregation by species identity, and they were mixed in cluster 1 (BCEAB424-16, BCEAB075-16, BCEAB611-17, BCEAB070-16, FBAQU1292-12, BCEAB383-16, BCEAB074-16, BCEAB072-16, ВCEAB069-16, BCEAB355-16) and cluster 2 (BCEAB073-16, BCEAB423-16, BCEAB071-16, BCEAB068-16, BCEAB404-16, FBAQU712-10). S. scotti (BCEAB024-16, BCEAB025-16, BCEAB026-6, BCEAB456-17, BCEAB457-17, BCEAB458-17, BCEAB459-17, BCEAB460-17, BCEAB461-17, BCEAB495-17) and $S$. fossarum, were markedly separated from the rest of Subsigara species.

\section{DISCUSSION}

In this work, we report the southernmost record of S. distincta in Europe and the first record of the species for Spain. The capture of $S$. distincta imagines and nymphs over the years of study, although not numerous, indicates that the species is a successful coloniser of the Pyrenean Lake Vilac. The lake matched the typical features of water bodies that $S$. distincta inhabit in the North-western and Central European regions (i.e. small size, silty substrate, high density of aquatic vegetation and low values of conductivity) (Aukema et al., 2002; Coulianos et al., 2008;
Klementová et al., 2015). In Slovakia, the species was found in a wide variety of environmental conditions not only in terms of elevation (151-1453 $\mathrm{m}$ a.s.1.), but also regarding $\mathrm{pH}$ (5.3-9.2) and conductivity $(9-580 \mu \mathrm{S} / \mathrm{cm})($ Klementová et al., 2015). Finding the species in mountain localities, however, becomes less common as one moves to higher latitudes, where $S$. distincta seems to prefer warmer waters at low altitude (Jastrey, 1981; Coulianos et al., 2008). Lake Vilac is not actually a typical high mountain lake, since it is situated at a relatively low altitude for these lakes in the Pyrenees, and therefore is one of the lakes with the highest water temperatures in the Pyrenees (I. Sabás pers. comm.).

Duursema (1996) found S. distincta to be an indicator of eutrophication and disrupted normal functioning of the ecosystem in Dutch ponds where the species was present in large numbers. Although dissolved inorganic nitrogen values were low in Lake Vilac, high total phosphorus concentration indicated that the lake was in a mesotrophic state (defined as $10<\mathrm{TP}<30 \mu \mathrm{g} / \mathrm{L}$, $3.5<$ Chl- $a<9 \mu \mathrm{g} / \mathrm{L}$; Smith et al., 1999), yet it was mainly due to its natural tendency to a eutrophic condition.

The metabarcoding results suggested a reliable morphological identification of female individuals and the presence of $S$. distincta nymphs in samples, as neither $S$. falleni nor S. fallenoidea DNA was detected. It is very likely that all the collected nymphs assigned to the triplet $S$. distincta/S. falleni/S. fallenoidea belonged to the first species. Many studies have already reported high-throughput sequencing technologies, and more precisely DNA metabarcoding, as a technique with an emerging application in routine monitoring protocols (Stein et al., 2014). The potential use of DNA barcodes during the pre-sorting of specimen-rich samples (versus morphology-based sorting) has also been highlighted, as it can help both in identifying immature stages and reducing the amount of morphological work carried out by taxonomists (Wang et al., 2018).

The presence of nuclear mitochondrial pseudogenes (NUMTs) can be the source of high genetic variability in a given morphospecies (Song et al., 2008), and their detection and removal are key steps in DNA metabarcoding 
studies (Liu et al., 2019). Despite employing highly degenerated primers during amplification, we found a single MOTU assigned to $S$. distincta and no similar artefactual sequences were detected during the bioinformatic pipeline. These results suggest the real nature of the DNA barcodes obtained in this work, with the occurrence of false sequences due to NUMTs being unlikely. In addition, the sequences of the full Folmer fragment were identical to the metabarcoding sequences, thus supporting this argument.

The species $S$. distincta, S. falleni, and $S$. iactans were previously found to compose a complex of species with low interspecific variation in COI by Havemann et al. (2018). Also, two distant haplotypes were described for $S$. distincta in their German samples. The two individuals sequenced in this study shared or were closely related to an isolated haplotype provided in Havemann et al.'s work. Thus, our results confirm the presence of that rare haplotype beyond the studied German localities, and support the existence of two divergent $S$. distincta lineages distributed throughout Europe. The implications of this finding will remain unclear until an in-depth revision of the molecular lineages and a validation of Subsigara taxonomic species is carried out.

Most likely, $S$. distincta reached the studied lake by dispersal flight from northern French localities, since no accepted records are published from the southern side of the Pyrenees. Nieser (1983) identified a female specimen found in southern Portugal as $S$. distincta, but the species record has not been included in subsequent publications because of its uncertainty. The broad range of habitats where the species can occur encourages us to expect the presence of $S$. distincta in water bodies close to Lake Vilac. Nevertheless, mountain ranges seem to have prevented the dispersal of the species and the colonisation of the southern slope of Pyrenees to date. Future biodiversity assessment studies will be needed to determine the range of distribution of $S$. distincta in Spain and southern Europe. Furthermore, the knowledge on intraspecific variability within corixid species complexes will benefit from forthcoming molecular studies covering underrepresented biogeographical regions.

\section{ACKNOWLEDGEMENTS}

We are very grateful to Jennifer Caner, Jeong-Soo Gim, Federica Lucati and Ibor Sabás, who helped in laboratory work, and to Marta Goula for providing informative bibliographic references. This work was funded by the European Commission LIFE+ project LIMNOPIRINEUS (LIFE13 NAT/ES/001210), and the Spanish Government projects FUNBIO (RTI2018-096217-B-I00) and BIOOCULT (2413/2017).

\section{REFERENCES}

CATALAN WATER AGENCY (ACA). 2004. Masses d'aigua subterrània de Catalunya. Massís Axial Pirinaic 40. Generalitat de Catalunya, Departament de Medi Ambient i Habitatge. https://aca-web.gencat.cat/aca/ documents/ca/fitxes_masses_aigua_subterrania/ mas_40_def.pdf. Accessed 20 Oct 2019.

AUKEMA, B. 2013. Fauna Europaea: Heteroptera, Corixoidea. Fauna Europaea version 2019.10. https://fauna-eu.org. Accessed 20 Oct 2019.

AUKEMA, B., J. CUPPEN, N. NIESER \& D. TEMPELMAN. 2002. Verspreidingsatlas Nederlandse wantsen (Hemiptera: Heteroptera). Deel I: Dipsocoromorpha, Nepomorpha, Gerromorpha \& Leptopodomorpha. European Invertebrate Survey - Nederland. Leiden, Netherlands.

CARBONELL, J. A., C. GUTIÉRREZ-CÁNOVAS, D. BRUNO, P. ABELLÁN, J. VELASCO \& A. MILLÁN. 2011. Ecological factors determining the distribution and assemblages of the aquatic Hemiptera (Gerromorpha \& Nepomorpha) in the Segura River basin (Spain). Limnetica, 30 (1): 59-70.

COULIANOS C.-C., J. ØKLAND \& K. A. ØKLAND. 2008. Norwegian water bugs. Distribution and ecology (Hemiptera-Heteroptera: Gerromorpha and Nepomorpha). Norwegian Journal of Entomology, 55: 179-222.

DUURSEMA, G. 1996. Vennen in Drenthe. Onderzoek naar ecologie en natuur op basis van macrofauna. Zuiveringsschap Drenthe. Assen, Netherlands. 
ELDER, J. F. \& J. C. SCHAEFFER. 2014. Observation récente de Sigara (Microsigara) hellensii (Sahlberg, 1819) et synthèse des connaissances sur sa distribution en France (Heteroptera, Corixidae). Bulletin de la Société entomologique de France, 119 (2): 191-195.

EUROPEAN COMMISSION. 1992. Council Directive 92/43/EEC of 21 May 1992 on the conservation of natural habitats and of wild fauna and flora. European Union Official Journal, 206: 7-50.

FOLMER, O., M. BLACK, W. HOEH, R. LUTZ \& R. VRIJENHOEK. 1994. DNA primers for amplification of mitochondrial cytochrome c oxidase subunit I from diverse metazoan invertebrates. Molecular Marine Biology and Biotechnology, 3: 294-299.

GELLER, J., C. MEYER, M. PARKER \& H. HAWK. 2013. Redesign of PCR primers for mitochondrial cytochrome c oxidase subunit I for marine invertebrates and application in all-taxa biotic surveys. Molecular Ecology Resources, 13 (5): 851-861. DOI: 10.1111/ 1755-0998.12138

HAVEMANN, N., M. GOSSNER, L. HENDRICH, J. MORINIÈRE, R. NIEDRINGHAUS, P. SCHÄFER \& M. J. RAUPACH. 2018. From water striders to water bugs: the molecular diversity of aquatic Heteroptera (Gerromorpha, Nepomorpha) of Germany based on DNA barcodes. PeerJ, 6: e4577. DOI: $10.7717 /$ peerj.4577

HÖREGOTT, H. \& C. H. C. JORDAN. 1954. Bestimmungstabelle der Weibchen deutscher Corixiden (Heteroptera: Corixidae). Beiträge zur Entomologie, 4 (5-6): 578-594.

HUELSENBECK, J. P. \& F. RONQUIST. 2001. MRBAYES: Bayesian inference of phylogenetic trees. Bioinformatics, 17 (8): 754-755. DOI: 10.1093/bioinformatics/17.8.754

IVANOVA, N. V., A. V. BORISENKO \& P. D. N. HEBERT. 2009. Express barcodes: racing from specimen to identification. Molecular Ecology Resources, 9: 35-41. DOI: 10.1111/j. 1755-0998.2009.02630.x

JANSSON, A. 1986. The Corixidae (Heteroptera) of Europe and some adjacent regions. Acta Entomologica Fennica, 47: 1-94.
JASTREY, J. 1981. Distribution and ecology of Norwegian water-bugs (Hem., Heteroptera). Fauna Norvegica Serie B, 28 (1): 1-24.

KATOH, K., K. MISAWA, K.-I. KUMA \& T. MIYATA. 2002. MAFFT: a novel method for rapid multiple sequence alignment based on fast Fourier transform. Nucleic Acids Research, 30 (14): 3059-3066.

KEARSE, M., R. MOIR, A. WILSON, S. STONES-HAVAS, M. CHEUNG, S. STURROCK, S. BUXTON, A. COOPER, S. MARKOWITZ, C. DURAN, T. THIERER, B. ASHTON, P. MEINTJES \& A. DRUMMOND. 2012. Geneious Basic: an integrated and extendable desktop software platform for the organization and analysis of sequence data. Bioinformatics, 28 (12): 1647-1649. DOI: 10.1093/bioinformatics/bts 199

KLEMENTOVÁ, B. R., P. KMENT \& M. SVITOK. 2015. Checklist of water bugs (Hemiptera: Heteroptera: Nepomorpha, Gerromorpha) of Slovakia. Zootaxa, 4058 (2): 227-243. DOI: 10.11646/zootaxa.4058.2.5

KRESS, W. J., C. GARCÍA-ROBLEDO, M. URIARTE \& D. L. ERICKSON. 2015. DNA barcodes for ecology, evolution, and conservation. Trends in Ecology \& Evolution, 30 (1): 25-35. DOI: 10.1016/j.tree.2014.10.008

LERAY, M., J. Y. YANG, C. P. MEYER, S. C. MILLS, N. AGUDELO, V. RANWEZ, J. T. BOEHM \& R. J. MACHIDA. 2013. A new versatile primer set targeting a short fragment of the mitochondrial COI region for metabarcoding metazoan diversity: application for characterizing coral reef fish gut contents. Frontiers in Zoology, 10 (1): 34. DOI: 10.1186/1742-9994-10-34

LIU, M., L. J. CLARKE, S. C. BAKER, G. J. JORDAN \& C. P. BURRIDGE. 2019. A practical guide to DNA metabarcoding for entomological ecologists. Ecological Entomology. DOI: 10.1111/een.12831

LOCK, K., T. ADRIAENS, F. VAN DE MEUTTER \& P. GOETHALS. 2013. Effect of water quality on waterbugs (Hemiptera: Gerromorpha \& Nepomorpha) in Flanders (Belgium): results from a large-scale field survey. Annales de Limnologie-International Journal of Limnology, 49 (2): 121-128. DOI: 
10.1051/limn/2013047

MURILLO, J. 1985. Clau per a la identificació dels heteròpters aquàtics (Nepomorpha) ibèrics. Butlletí de la Institució Catalana d'Història Natural, 52: 149-159.

NIESER, N. 1982. De Nederlandse water - en oppervlakte wantsen: (Heteroptera: Nepomorpha en Gerromorpha). Wetenschappelijke Mededelingen Koninklijke Natuurhistorische Vereniging, 155: 1-103.

NIESER, N. 1983. Faunistical notes on aquatic Heteroptera VI. Records from Portugal and some Mediterranean localities. Ciência Biológica, Ecology and Systematics, 5: 105-115.

NIESER, N., M. BAENA, J. MARTÍNEZ-AVILES \& A. MILLÁN. 1994. Claves para la identificación de los heterópteros acuáticos (Nepomorpha y Gerromorpha) de la Península Ibérica - Con notas sobre las especies de las Islas Azores, Baleares, Canarias y Madeira. Asociación Española de Limnología. Madrid. Spain.

POLHEMUS, J., A. JANSSON \& E. KANYUKOVA. 1995. Infraorder Nepomorpha. In: Catalogue of the Heteroptera of the palaearctic region. Vol. 1. Enicocephalomorpha, Dipsocoromorpha, Nepomorpha, Gerromorpha and Leptopodomorpha. B. Aukema \& C. Rieger (eds.): 26-56. The Netherlands Entomological Society, Amsterdam, Netherlands.

POPHAM, E. J., M. T. BRYANT \& A. A. SAVAGE. 1984. The role of front legs of British corixid bugs in feeding and mating. Journal of Natural History, 18 (3): 445-464.

POSADA, D. 2008. jModelTest: phylogenetic model averaging. Molecular Biology and Evolution, 25 (7): 1253-1256. DOI: 10.1093/ molbev/msn083

PROSSER, S., A. MARTÍNEZ-ARCE \& M. ELÍAS-GUTIÉRREZ. 2013. A new set of primers for COI amplification from freshwater microcrustaceans. Molecular Ecology Resources, 13 (6): 1151-1155. DOI: 10.1111/ 1755-0998.12132

RATNASINGHAM, S. \& P. D. N. HEBERT. 2007. BOLD: The Barcode of Life Data System (http://www.barcodinglife.org). Molecular Ecology Resources, 7 (3): 355-364.
DOI: $10.1111 / \mathrm{j} .1471-8286.2007 .01678 . x$

SMITH V. H., G. TILMAN \& J. C. NEKOLA. 1999. Eutrophication: impacts of excess nutrient inputs on freshwater, marine, and terrestrial ecosystems. Environmental Pollution, 100 (1-3): 179-196.

SONG, H., J. E. BUHAY, M. F. WHITING \& K. A. CRANDALL. 2008. Many species in one: DNA barcoding overestimates the number of species when nuclear mitochondrial pseudogenes are coamplified. Proceedings of the National Academy of Sciences, 105 (36): 13486-13491. DOI: 10.1073/pnas.0803076105

STAMATAKIS, A. 2014. RAxML version 8: a tool for phylogenetic analysis and post-analysis of large phylogenies. Bioinformatics, 30 (9): 1312-1313. DOI: 10.1093/bioinformatics/ btu033

STEIN, E. D., M. C. MARTINEZ, S. STILES, P. E. MILLER \& E. V. ZAKHAROV. 2014. Is DNA barcoding actually cheaper and faster than traditional morphological methods: results from a survey of freshwater bioassessment efforts in the United States?. PLOS ONE, 9 (4): e95525. DOI: 10.1371/journal.pone.0095525

SWOFFORD, D. L. 2003. PAUP*. Phylogenetic Analysis Using Parsimony (*and Other Methods). Version 4. Sinauer Associates. Massachusetts, USA.

THOMSEN, P. F. \& E. WILLERSLEV. 2015. Environmental DNA-An emerging tool in conservation for monitoring past and present biodiversity. Biological Conservation, 183: 4-18.

VENTURA, M., L. CAMARERO, T. BUCHACA, F. BARTUMEUS, D. M. LIVINGSTONE \& J. CATALAN. 2000. The main features of seasonal variability in the external forcing and dynamics of a deep mountain lake (Redó, Pyrenees). Journal of Limnology, 59: 97-108. DOI: 10.4081/jlimnol.2000.s1.97

WANG, W. Y., A. SRIVATHSAN, M. FOO, S. K. YAMANE \& R. MEIER. 2018. Sorting specimen-rich invertebrate samples with cost-effective NGS barcodes: Validating a reverse workflow for specimen processing. Molecular Ecology Resources, 18 (3): 490-501. DOI: 10.1111/1755-0998.12751 